UDC 2-1

\title{
Transfiguration of Moses and Enoch on Heaven and the Adamic condition
}

\author{
T. Garcia-Huidobro \\ Pontifical Collegium Russicum in Rome, \\ 2A, Via Carlo Cattaneo, 00185, Roma RM, Italy
}

For citation: Garcia-Huidobro T. Transfiguration of Moses and Enoch on Heaven and the Adamic condition. Issues of Theology, 2020, vol. 2, no. 3, pp. 390-408.

http://doi.org/10.21638/spbu28.2020.301

In Second Temple Judaism, especially in apocalyptic literature, the encounter between God and believers acquires a distinct visionary accent. Regardless of whether heavenly realities are revealed on earth or the visionary ascends to heaven, the essence is the manifestation of important revelations. Corresponding Old Testament heroes, such as Enoch or Moses, according to apocryphal, Samaritan or rabbinic texts, ascended to the place of God's presence (a throne room or even a cloud). In addition to receiving relevant soteriological and cosmological knowledge, they underwent transfiguration there. The transfiguration of these characters is very illustrative: they take angelic, royal, and priestly qualities. Divine radiance, shining faces, and magnificent robes are just some examples of the divine characteristics that are acquired. This article, together with the study of these elements, underlines the fact that these divine qualities were described in the literature around the change of era and dedicated to Adam prior to his expulsion from Eden. The closeness between the first man and God in the Garden of Eden was expressed in a number of divine attributes inherent in Adam, the same ones that would later be assumed by Enoch or Moses, among others, in heaven. In this way, the transfiguration of Enoch or Moses is nothing more than a manifestation of the rich Jewish anthropology of an Adamic character.

Keywords: Adam, Moses, Enoch, transfiguration, heaven.

\section{Introduction}

Traditionally the temple of Jerusalem represents the place where the sanctity of God is found in the clearest way and from where it irradiates to the rest of the city, the country and finally to the creation. The sanctuary was the location where God meets his people, prepared accordingly through the ritual and moral purity, specially through the celebration of its feasts and sacrifices. However, there is also a canonical and apocryphal speculation about some Old Testament heroes,

(c) Санкт-Петербургский государственный университет, 2020

(c) Общецерковная аспирантура и докторантура им. святых равноапостольных Кирилла и Мефодия, 2020 
such as Enoch, Abraham, Melquizedek, Jacob, Moses, among others, who have had access to the heavenly realities either ascending to the heavens or through visions that happen in earth when the heavens are "open". In these speculations the encounter between the divinity and the visionary acquired a much more dramatic accent. One of the consequences of this meeting is the transfiguration suffered by the protagonist who assumes many divine properties which coincides with the qualities Adam had in the Garden of Eden. In the present paper, we will address two paradigmatic examples of the precedent statement: that of Moses and the Enoch (according to the 2Enoch).

\section{The example of Moses}

\subsection{Moses ascends to an heavenly realm}

After the liberation of the slavery in Egypt, Moses leads the people of Israel through the desert to the base of the Sinai mountain on which's top he will meet God. Although the texts of Ex 24:1-2, 9-18 and 34:29-35 do not strictly refer to a Moses's heavenly journey to reach the throne of God, the early mystical interpretation of them gave rise to speculations especially relevant to us.

Let's start with the first and most obvious of the elements, Moses ascends a high mountain, the Sinai, to meet God. In Ex 24:12 God tells the Patriarch to

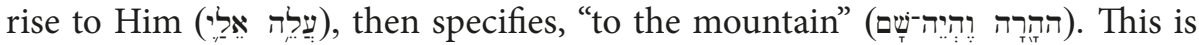

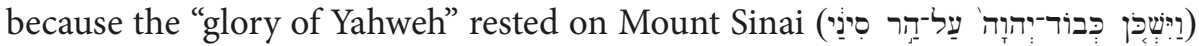
(Ex 24:16). Josephus, in the first century, points out that Moses ascended to Sinai, the "highest mountain of that land" which is not only "difficult for men to climb because of its enormous height, but also because of the steepness of its precipices. You can't look at it without feeling sore eyes. Moreover, it was terrible and inaccessible because of the rumor that God dwelt in it" (Ant. III, 5, 1) ${ }^{1}$. This element should not surprise us because it is in the mountains where, according to some ancient traditions, epiphany occurs. Thus, for example, in The Book of Watchers (1Enoch 18:6-8) we are told that when Enoch travels south he found seven mountains of precious stones, the middle one being the highest, reaching to touch the sky "like the throne of God". The same relationship occurs between the "mountain" and the "throne" of God in the Exagogue of Ezekiel the playwright where Moses is enthroned once he goes up to Sinai. Indeed, on top of the Sinai, Moses contemplated what looked like a throne, so huge that it touched the clouds of heaven. On the throne was sat a man of noble countenance. In one hand he carried a scepter while with the other he called him. Then Moses approached and stood before the throne. God took the scepter and invited him to climb the throne, then gave him the crown and he himself withdrew from the throne. Moses looked at all the earth around, the things that are under it and

${ }^{1}$ In this paper we will use the following translation: Josefo $F$. Antigüedades de los judíos (Ant.). Barcelona: Cloe, 2013. 
above the sky. A multitude of stars, and their number was uncountable, fell at their feet. They passed by him like an army ${ }^{2}$.

The fact that, according to some traditions, a "throne" is found at the top of Sinai as a manifestation of divine power, should not surprise us. After all, this is where the divine "cloud" is also found:

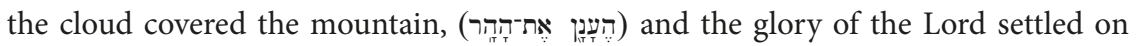
Mount Sinai. For six days the cloud covered the mountain, and on the seventh day

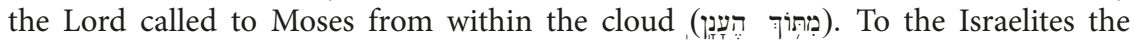

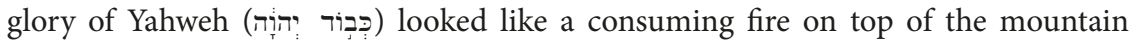

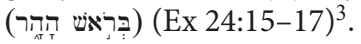

As we know the "cloud" is a way of referring to the glorious presence of God (Ex 13:21; 40:34-35; Deut 31:15; 1Kings 8:10-13; 2Mac 2:8). This cloud at Sinai is so sublime that the author of Eclo will refer to it as a "dark cloud" (Eclo 45:5). Philo of Alexandria will also refer to it in an apophatic way in De vita Mosis (De Vita Mos.) $)^{4}$ speaking of "darkness" instead of "cloud". This text is interesting because the "darkness" is like a door which open for us a completely different dimension from the faulty reality we know. The text says that Moses entered "in the darkness where God was, that is, in the immaterial, invisible, incorporeal and archetypal essence of the existing" (Vita Mos. I:155-158). In that same sense, in Quaestiones et solutiones in Exodum (Quaest. Ex.) ${ }^{5}$ the philosopher tries to answer about the meaning of the following phrase that God addresses to Moses:

${ }^{2}$ Halladay C. Fragments from Hellenistic Jewish Authors, vol. II. Atlanta: Scholar Press, 1989. P.363-365. - This identification between the mountain and the throne of God will be important in the synoptic accounts of the transfiguration when the divine voice identifies Jesus as his son, occupying real formulas such as 2Sam 7:14 ("I will be for him a father and he will be for me a son") and Ps 2:7 ("You are my son, today I have begotten you"). In this case it will also be the top of a hill (the Tabor) the setting of the enthronement. C. A. Gieschen reminds us about an objection to this interpretation of the enthronement of Jesus in the manner of Moses on the top of the mountain is given by the fact that he remains standing all the time and is never mentioned to take a seat. But God Himself is described as "standing" in Deut 5:31 when he says to Moses: "You stay here with me, that I want to communicate all the commandments to you". For more details: Gieschen C. Angelomorphic Christology: Antecedents and Early Evidence. Leiden: Brill, 1988. P.31. - We can add another example, although it does not strictly talk about the enthronement of the protagonist, that is the one found in the 2Enoch where Enoch is promised to remain standing in front of the face of the Lord for eternity instead of sitting beside the divinity.

${ }^{3}$ The reference of the cloud that descends and covers the top of the mountain is also an important reason in the synoptic accounts of the transfiguration. As A. Orlov reminds us, the cloud that covers Jesus and his three companions is bright (הנתוש הלשֶ) according to the version of Mt. The Lucan version has the peculiarity of speaking that the protagonists "entered the cloud" as if it were a place in the manner of Eclo or Philo of Alexandria. It is through this cloud that the divine voice will be manifested in the manner of a revelation (Mt 17:5; Mc 9:7; Lk 9:35). See: Orlov A. The Glory of the Invisible God: Two Powers in Heaven Traditions and Early Christology. London: T\&T Clark, 2019. P. 110-115.

${ }^{4}$ In the present work we follow the translation of Vita Mos. from: Triviño J. M. (trad.) Obras Completas de Filón de Alejandría, vol. IV. Buenos Aires: Acervo Cultural, 1976.

${ }^{5}$ In this work we will use the following translation of Quaest. Ex. from: Marcus R. Philo, Questions and Answers on Exodus. Cambridge: Harvard University Press, 1963. 
"go up to the mountain and stay there" (Ex 24:12). The answer would be given in the transformation of the holy soul that can ascend "to the region above the heavens beyond the world where there is no place except God". In the same way, according to Samaritan theology collected in Memar Marqah 6:3, the cloud at the top of the mountain was not of a gaseous nature but a veil that separated the visible world from the invisible. When Moses penetrates the cloud, he is truly entering the celestial world in which reality is no longer flawed as it is on earth ${ }^{6}$.

The presence of God on the top is reflected not only through the "throne" or the "cloud" but also through the visual and acoustic theophany that takes place there. The traditions contained in the texts are diverse. On the one hand, they point to a physical presence of the divinity like the one we mentioned of the man of noble countenance who was sitting on the throne before giving it to Moses in the Exagogue. Ex 24:9 also points to a physical appearance of God when we are told that Moses came up to Sinai with Aaron, Nadab and Abihú, accompanied

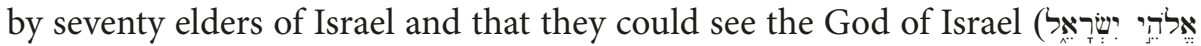

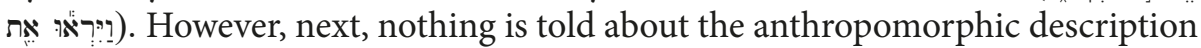
of God. The only thing mentioned is that He has feet, hands, a face and a huge

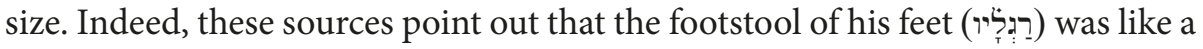

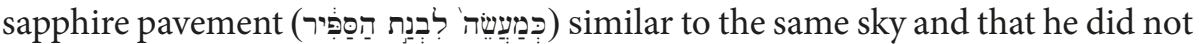
extend his hand ( $\mathrm{Ad}=\mathrm{y}$ " $\mathrm{xl} ; \mathrm{Pv}$ ' al $\{$ ) over the authorities of Israel (Ex 24:10-11). It is interesting to note also that the elders not only contemplated God (ואתדיהאלה (וזים

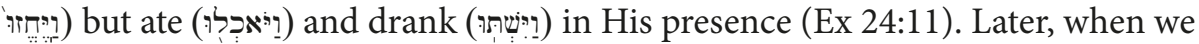
stop at the metamorphosis of Moses, we will see how these two particular verbs were interpreted. Other sources emphasize that God has a face.

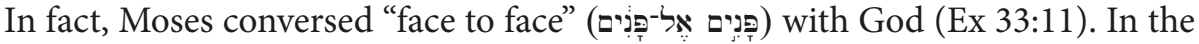
same chapter, however, when Moses asks God to show him his "glory" (כָבדָך) (Ex 33:18), He replies that His goodness will pass before he and who will be able to pronounce the Name of Yahweh, but to contemplate his "Face" (

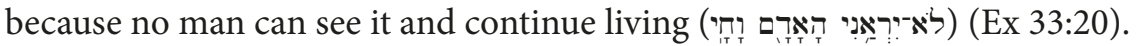

The divine theophany is manifested, then, through the "throne", the "cloud" or the "extraordinary greatness" of divinity at the top of Sinai. But there is more. Another way to emphasize the divine mystery that transcends all understanding is through acoustic theophany. As we know, in certain apocryphal works, God is present through his voice that comes from beyond any conception that we can make of Him. Let consider the next texts taken from the Slavic apocrypha The Apocalypse of Abraham which happens after Abraham has ascended to heaven to stay before the Merkabah:

${ }^{6}$ Three are the roots of Samaritan religiosity: the Torah, whose version is different from the Jewish one; the translation of the Torah into the Samaritan language and the Memar Merqah composed between the third and fourth century in Aramaic by a Samaritan philosopher named Mark. The latter is a midras of the Torah in six books that begins with the story of the burning bush and ends with the death of Moses. It focuses, then, on the figure of Moses, the only prophet that has existed according to the Samaritan tradition. The Greek influence in this text is evident. For more details: MacDonald J. The Theology of the Samaritans. London: SCM Press, 1964. P. 181. 
And while he (Abraham) was still speaking, behold the fire coming toward us round about, and a voice was in the fire like a voice of many waters, like a voice of the sea in its uproar. And the angel knelt down with me and worshiped (17:2).

Further in the same text we read:

And as I (Abraham) was still reciting the song, the mouth of the fire which was on the firmament was rising up on high. And I heard a voice like the roaring of the sea, and it did not cease from the plenitude of the fire (18:1).

Another apocryphal example is found in the Ladder of Jacob A 2:1-3:

And when I (Jacob) heard this from on high, awe and trembling fell upon me. And I

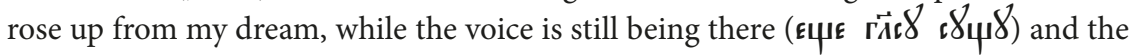
word of God in my ears, and I said: "How fearful is this place! This is none other than the house of God and this is the gate of heaven".

As we remember, these texts describe the greatness of everything that surrounds God: the "throne", the "cherubs", the "angels". Although everything is magnificent, nothing is told of God himself. The divine presence is manifested through his voice. This idea is present also in Ex 4:16 when God makes himself present through his word beyond the "throne" or from the "cloud": "On the

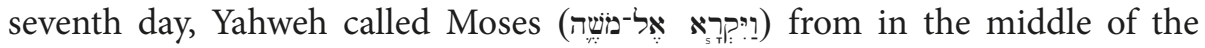

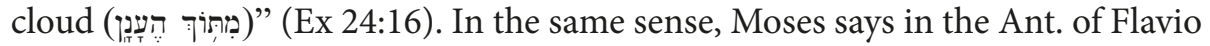
Josephus: "I have been received before God and have heard his incorruptible voice" (IV, 5, 3). However the mystical experience could be described, one thing is sure, Moses suffered one remarkable transfigurations as a result of it.

\subsection{The transfiguration of Moses}

As a result of the theophany Moses is transfigured ${ }^{7}$. The texts are very expressive. As we have seen, in the Exagogue we are told that once Moses

7 The synoptic reflection on the transfiguration of Jesus drinks from the experience of Moses in Ex 24:1-2; 9-18; 34:29-35. The use of the passive verb $\mu \varepsilon \tau \varepsilon \mu о \rho \varphi \omega \dot{\theta} \eta \eta$ used by both Mk and Mt implies "to be transformed" or "change the form into". As M.D. Hooker points out ("What are you doing here, Elijah?” // Hurst L.D., Wright N.T. (eds) The Glory of Christ in the New Testament. Oxford: Oxford University Press, 1987. P. 60) this is the same verb that St. Paul uses in Rom 12:2 and 2Cor 3:18, in the latter case, to refer to Christians who "with the naked face reflected as in a mirror the glory of the Lord, we are transforming ( $\mu \varepsilon \tau \alpha \mu о \rho \varphi о v \mu \varepsilon \theta \alpha)$ in that same image". In Mk this metamorphosis is expressed in that "his clothes [those of Jesus] became shining, very white" [so much that no baton on earth could bleach them in that way] (Mk 9:3); while Mt refers not only to her white dresses but also to the light that shines from her face: "her face became bright as the sun and her dresses became white as light" (Mt 17:2). Finally, in Lk "the appearance of his face changed, and his clothes were of a blazing whiteness" (Lk 9:29). The shining whiteness of Jesus' clothes brings us several images that tell us about the glory of God. The first is Ps 104:1-2, which refers to the light dresses of God: "Dressed in splendor and majesty, the light clings to you like a mantle". Another example is the Ancient of Days dresses [reference to God] in Dn 7:9 that "were snow white". For his part in The Book of Watchers Enoch describes the garments of glory (1Enoch 14:8) of God saying that «his robe was brighter than the sun and more resplendent than hail" (1Enoch 1:20). The transfiguration, therefore, is related to the revelation of the divine glory that Jesus reflects through his clothes. But there is more because, in addition to the clothes, the versions of Mt and Lk refer to the luminous face of Jesus. The same happens with the divine glory in 1Enoch 
ascended to heaven he was recognized as King and Judge over creation and over a multitude of angels ${ }^{8}$. In Eclo 44:23-45:5 we are told that Moses was revealed "the glory of God" upon receiving the Torah because the divinity was given "face to face" (Eclo 45:5). As A. Orlov reminds us, this visionary experience also entails the transformation of Moses because he was granted the "glory of the angels", besides that God made him powerful and feared by his enemies (Eclo 45:2), and made him a priest and mediator between God and his people (Eclo 45:5). At the same time, C. Fletcher-Louis10 points to the transfiguration of Moses in some texts of the Qumran. In 4Q374 frag. 2 col. II, two texts are combined, the first is Ex 7:1 when divinity makes Moses "as God before Pharaoh"; the second is Ex 34 when Moses descends from Mount Sinai and God makes "his face shine". In this way, Moses appears as a theophany in front of the Pharaoh, his bright face shining on "those who were to be healed" and as a result "they strengthened their hearts again and knowledge $<\ldots$. .". On line 9 it is said that despite "nobody knew you, they vanished and trembled". Both aspects, healing and fear, are part of the elements of the theophany that are preached in this case of Moses. The second text of the Qumran is 4Q377 fragment 1 column II which talks about the divinization of Moses during his ascension to Sinai. In lines 9-11 the image of the people is contrasted with Moses. While the former keeps trembling and away from the "glory of God" and the "magnificent thunder", Moses was with God in the cloud where he was "sanctified and spoke with his mouth like an angel, because has there been a messenger like he, a godly man like him?".

One of the clearest expressions of this metamorphosis of Moses is found in the light radiating from his face. As is well known when Moses came down from

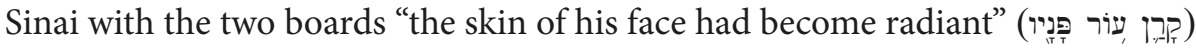
(Ex 34:29). In fact, the reaction of Aaron and all the Israelites to this portent was fearful of approaching him. Despite this, Moses called them and conveyed all that was said by Yahweh, thus, "when [he] finished speaking with them, he put a veil on his face. Whenever Moses appeared before Yahweh to speak with him,

14:21, which is reflected not only in his clothes, but also in the face of the "Glorious and Excels" whose appearance cannot be contemplated by any man. And it is that a "scorching fire surrounds him, a great fire rises before him, and there is no one who approaches those around him". In the 2Enoch the face of the Lord is also mentioned when the protagonist speaks of his experiences in the heavens: "I contemplated the face of the Lord similar to a hot iron that, when removed from the fire, emits sparkles and you are seeing my eyes, men of a man who has been created just like you, but I have seen the eyes of the Lord as a beam of sun rays that dread human eyes" (2Enoch 13:5-6). Thus, it seems that like the clothes, the transfigured face of Jesus reflects the glory of the face of God.

${ }^{8}$ Holladay C. Fragments from Hellenistic Jewish Authors, vol. II. Atlanta: Scholar Press, 1989. P.363-365.

9 The angelic character of Moses will also be collected by rabbinic literature. Thus, in PRE 48 it is pointed out that at birth his body was like that of an angel of God. In the same way b.Sot points out that the house where the patriarch was born was filled with light. For its part, DtR 11.10 indicates that Moses was able to speak the day he was born. Other texts on the same line would be ExR 1.20 and Zohar II, 11b. For more details: Orlov A. The Glory of the Invisible God. P. 102.

${ }^{10}$ Fletcher-Louis C. All the Glory of Adam. Liturgical Anthropology in the Dead Sea Scrolls. Leiden: Brill, 2002. P. 136-142. 
he removed his veil until he left $<\ldots>$. The Israelites saw the skin of the face of

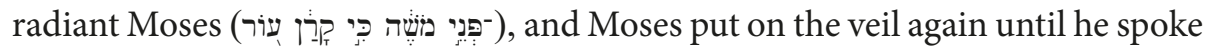
with Yahweh again" (Ex 34:29-35) ${ }^{11}$. In the Biblical antiquities, the Pseudo-Philo tells us that "the light of his face" when he came down from Sinai,

was superior to the splendor of the sun and the moon, but he ignored it. When he descended with the Israelites, they did not recognize him when he saw him. They recognized him when he spoke to them $\langle\ldots\rangle$. Then, when Moses learned that his face had such a radiance, a veil was made to cover his face $(12: 1)^{12}$.

In the same work it is pointed out that the appearance of Moses before his death, when he ascends the Nebo / Abarim, "became glorious, and he died in glory according to the word of God" (AntBib 19:16). Separate case are the numerous references to the divine transformation of Moses according to Philo of Alexandria. For the philosopher, Moses entered "in the darkness where God was, that is, in the immaterial, invisible, incorporeal and archetypal essence of the existing" (De Vita Mosis I:155-158). There his mind became so inspired by the divine way that "it became like a unit, without being mixed with anything that can be associated with duality". And it has left behind "all kinds of mortal elements, having moved to the divine, becoming familiar with God and truly divine" (Quaestiones et Solutiones in Exodum 2:29) ${ }^{13}$. In De Virtutibus 76 (De Virt.) ${ }^{14}$ Moses' transformation arises "from a mortal existence to an immortal life". In this process the prophet notes that his body "moved, that it was growing like the shell of an oyster, while its soul, calm, began its migration".

Finally, let's say something about the transformation of Moses in the heavens according to Samaritan sources. The expression "Moses was dressed in light" is frequent in Memar Marqah, a statement parallel to that of being dressed or crowned with the name of God, which implies the metamorphosis of a divine state. The image of God is somehow recorded in Moses when he descends from

${ }^{11}$ In the rabbinic literature we can mention the Targum Pseudo-Jonathan (PsJon) to Ex 34:29 who reads: "When Moses descended from Mount Sinai $\langle\ldots\rangle$ he did not know of the splendor that the iqonin of his face shone because of the brightness of the Glory of the Shekinah of the Lord when they spoke". On Ex 34:30 it is said: "Aaron and all the children of Israel looked upon Moses and, look, the iqonin of his face shone. And they feared approaching him. Finally, of the v.v. 33-35 it is said: "When Moses finished speaking with them, he put a veil over the iqonin of his face. When Moses went before the Lord to speak with him, he removed the veil that covered the iqonin from his face until he left. Then, he went out and told the children of Israel what [God] had asked for. The children of Israel could see the iqonin of Moses truly shining. Then Moses could put the veil on his face again until he spoke to Him again". For more details: Orlov A. The Glory of the Invisible God. P. 126.

${ }^{12}$ In this work we quote the translation of: Fuente Adánez A. De la (trad.) Antigüedades Bíblicas (Pseudo-Filón) // Díez Macho A. (ed.) Apócrifos del Antiguo Testamento. Vol. II. Madrid: Cristiandad, 1983. P.209-310.

${ }^{13}$ Marcus R. (trad.) Philo, Questions and Answers on Exodus. Cambridge: Harvard University Press, 1963. P. 70.

${ }^{14}$ In this work we quote the translation of: Triviño J.M. (trad.) Obras completas de Filón de Alejandría. Vol. V. Buenos Aires: Acerbo Cultural, 1976. 
the heavens: "His image (that of God) lived in him. How terrible for all those who contemplated it, no one look at it straight ahead!" (Memar Marqah 6:3). Likewise, it is stated in Memar Marqah 5:3:

How great the hour in which the great prophet Moses stopped at the top of Mount Nebo and all the heavenly angels honored him $\langle\ldots\rangle$ ! Great was the joy that Moses' heart felt when he saw the angels around him, right and left, in front of and behind him! The Great Glory took him by the right hand and walked before him.

It is interesting that in Memar Marqah Moses is dressed in the light or name of God. The following text is very illustrative in this regard:

Exalted is the great prophet Moses whom God clothed with his Name $<\ldots$. . The Four Names led him to the waters of life to be exalted and honored in every place: the name with which God clothed him; the name that God revealed to him; the name through which God glorified him; the name through which God exalted him $\langle\ldots\rangle$. The first name, with which he opens the book of Genesis, was with which [Moses] was clothed and through which he was made strong $(4: 7)^{15}$.

In Memar Marqah 6:3 it is mentioned that in heaven he was given food of angels ${ }^{16}$ : "He was supplied with angel food. They sat him at the table of angels and ate his bread". The issue of food is very important when we talk about the transfiguration of Moses. Already in Ex 24:11 we are told that Moses and the

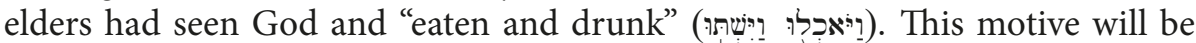
specially developed through rabbinic literature. Thus in the Leviticus Rabbah, R. Johanan points out that the food with which Moses and the elders fed on Sinai was the divine light because, as it is said, «the light of the king's countenance is life» (Prov 16:15). On the other hand, we read in Exodus Rabbah (ExR) 45:5:

R. Hoshaiah Rabbah said: He [Moses] did something good when he hid his face. The Holy One, blessed be, said: "I came to show you my face and you honored me and hid your face. For your life! You will be with me on the mountain for forty days and forty nights without eating or drinking because you will be fed with the splendor of the Shekina as it is said: 'And Moses did not know that his face was radiant because he had spoken with the Lord"' (Ex 34:29). But Nadab and Abihu discovered their heads and their eyes ate the splendor of the Shekina.

In this text, being fed by the Shekina's radiance is something positive. What distinguishes Nada and Abihu from Moses is the respect that one and the other showed for the honor of God. While Moses hides his face as a sign of respect for the Face of God, Nada and Abihu contemplate the divine Face and eat of it when observing it. The connection between this food and the splendor of the Shekina in relation to Moses and the angels is described in another text, ExR 47: 7: "It was a good thing for Moses to fast 120 days when he received the Torah. How did

\footnotetext{
${ }^{15}$ MacDonald J. The Theology of the Samaritans. P. 80-81.

${ }^{16}$ Ibid. P. 400-401.
} 
Moses feed? Of the splendor of the Shekina, as it is said: 'And you provide sustenance for all of them'. 'And with your eyes you will see your teacher' (Is 30:20)".

Clearly, the fact that Moses assumes divine qualities as a result of his ascension to Sinai and his encounter with divinity not only constitutes a remarkable fact but also opens up a series of questions in relation to human nature that is capable of withstanding such transformation. How is it possible that human nature, with all its precariousness, can assume divine properties? Canonical, apocryphal and rabbinic texts seem to give us an interesting answer that leads us to the adamic nature we all share.

\subsection{The adamic character of the Moses's transfiguration}

The metamorphosis of Moses at the top of Sinai is impressive because it consists in assuming supernatural qualities. The patriarch enters the "cloud" or "glory" (Ex 13:21; 24:15-17; 40:34-35; Deut 31:15; Eclo 44:23-45:5; 4Q 377 frag. 1 col II; Vit. Mos I:155-158; Memar Marqah 6:3); it assumes the "real" character proper to divinity (1Enoch 18:6-8; Exagogue); acquires the appearance of an angel (Eclo 45:2; 4Q377 frag. 1 col II:9-11); it possesses the divine "luminosity" or "radiance" (Ex 34:29-35; 4Q374 frag. 2 col. II; Ant. Bib 12:1; 19:16; Memar Marqah 4:7; 5:3); it fed by the "presence" of God (Ex 24:11; Memar Marqah 6:3; ExR 45:5; 47:7). It should not be forgotten that Moses has passed from a mode of existence characterized by "life" and "death" that is, by the "precariousness" and "corruptibility" of the relative order (Gen 2:7; 3:19; Ps 104:29-30; Eccles $3: 19 ; 12: 7$; Job 34:14-15, etc.), to "glory", "incorruptibility", and "immortality" of the divine. Now, how do we explain an ontological change of that size? It is not enough just to verify the gift of God, to all obvious evidences in these stories. There must be another element that explains this metamorphosis. Some anthropological aspect that serves as a "vessel" to the divine qualities assumed by those who ascend to the presence of God. Indeed, this factor is found in the "nature" of the human being who was created by God in his "image" and "likeness". Indeed, it is this "image" and "likeness" of the first man the foundation that explains that it can be "divinized". And, as it is well known, according to several texts on the creation of Adam, God not only provided man, as a gift, "life" at the time of creating him. The first man participated in the same divine qualities that Moses adopts at the time of his celestial metamorphosis.

Indeed, participating in the "glory", the "luminosity" and the "power" of God is a quality that Moses shares with the first couple. Recall that in the Armenian version of Life of Adam and Eve (LifAd) 44:20 when the woman ate the forbidden fruit, she learned that "she was naked from the glory with which she was dressed"17. Then, horrified she began to cry, while she reproached the snake: "What have you done with me?". This recrimination will be repeated later

17 The Greek version changes the expression "nude of glory with which she was dressed"

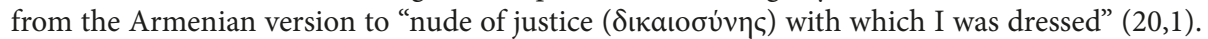
This is explained through Ps 17:15 where we read "As for me, in righteousness (קדֶצב) I will contemplate your face (זרינָסָ)". Throughout this work, unless explicitly indicate another one, we will 
through Adam when the woman is deceived a second time by the Devil. In the Latin version of the LifAd the first man exclaims loudly: "Woe to you, Devil! Why do you fight against us? Why do you take care of us? What have we done to you to persecute us with such determination?" (LifAd 11:2). The Devil, then, begins to reproach Adam that,

when God breathed into you the breath of life and your countenance and likeness (est vultus et similitudo) were made in the image of God, Michael took you and made you worship in the presence of God $(13: 2)<\ldots>$ Michael then called all the angels saying: "Worship the image of the Lord, as the Lord has commanded" (14:1).

Then, the Devil refused because he considered Adam of less category and younger than him. This attitude causes many angels to follow his example, which provoked the wrath of God who expelled him from his glory (LifAd 14:3-16:1). What is particularly interesting about the Latin version of the LifAd is the mention of the "face" (vultum) of Adam created in the image of God and, therefore, being the object of angel's worship. It is as if Adam's face shared the same radiance as God's. Moreover, after this intense dialogue between the Devil and Adam, the latter begs God to move this adversary away from him, and to give him "his glory, which he himself lost" (da mihi gloriam eius, quam ipse perdidit) (LifAd 17:1). In the same way, and according to PRE 14 and 20, when the first couple ate the fruits of the tree, "the cloud of glory" that covered them left them. In GnR 12:6 it is mentioned that once man sinned, his "brightness" was subtracted (based on Job 14:20). In the Book of the revelations of Clement it is said that after eating the deadly fruit, "they were stripped of their glory and were naked from the light they clothed" (5:3). In the same way, b.Hag $12^{\text {th }}$ tells us that the opinion of some rabbis regarding the first thing Adam lost after sinning was the precious primordial light that God hastened to hide. In LvR 20:2 the Adamic radiance is also mentioned in a way that reminds us of that of Moses at the time of descent from Sinai:

Resh Lakish, on behalf of R. Simeon the son of Menasia, said: “The apple of Adam's heel eclipsed the glare of the sun; How much more the brightness of his face! You don't even need to be amazed. In an ordinary way if a person makes trays, one for himself and one for his house, which one will make it more beautiful? Won't it be what he does for himself? Similarly, Adam was created for the service of the Holy One, blessed be, and the sun for the service of mankind".

Thus, the expulsion of the first couple from Paradise implied the awareness of their precariousness or mortality, together with the loss of intimacy and immediacy with God reflected in the glory that the divinity shared with them. This is the same "glory", "radiance" and "power" that Moses experienced through his metamorphosis at Sinai. As Memar Marqah 5:4 points out well when it tells us

follow the translation of: Anderson G. A. ; Stone M. E. (eds.) A Synopsis of the Books of Adam and Eve. Atlanta: Scholars Press, 1999. P.58e. 
that Moses "was dressed in the way Adam was in the Garden of Eden. His face shone until the day of his death"18.

Another similar aspect between Adam and Moses, which is generally overlooked, is the enormous size they both possess. While the texts that refer to the greatness of the size of Moses in Sinai are not numerous, they are indicative of the existence of a tradition in this regard. Indeed, remember that when Moses ascends to Sinai in the Exagogue he finds a throne so large that it touched the clouds of heaven. The impressive proportions of the throne in question forces one to think that the man of noble countenance who sat on him was also enormous. Therefore, when Moses is crowned with his diadem, he sits on his throne, and contemplates the earth together with the things that are under it and above the sky, it is assumed that he has the divine dimensions. Filon of Alexandria (De Virt. 76) points out that the body of Moses moved to the extent that «it was growing like the shell of an oyster». In the case of Adam, the examples are more abundant. Thus, to mention only a few, the Apocalypse of Abraham (ApAb) describes Adam as «a very large man of tremendous size and of corpulence, of an incomparable appearance» (23:3). According to 2Enoch, the first man covered the four corners of the world: East, West, North and South (11:63). The idea of Adam covering the four cardinal points is repeated in GnR 8:1 when we are told that it was created as an inanimate mass that "extended from one end of the world to the other". In PRE 11 he mentions that the height of the first man went from west to east. In t. Hag $12^{\text {th }}$ his height is described as the distance between heaven and earth, covering east to west, from north to south.

Understanding Moses as a second Adam is reinforced if we consider that the creation account has an open end that culminates in the delivery of the Torah at Sinai. And the parallels between Gen 1-3 and the Exodus account are evident. The Ex tells us that the glory of the Lord rested on Mount Sinai, and the cloud covered it for six days; and on the seventh the divinity called Moses from the midst of the cloud (Ex 24:16). Then God gives him the provisions for the construction of the Shrine (Ex 25-31) that follow the same structure of creation in Gen 1: "seven speeches" (Ex 25:1; 30:11, 17, 22, 34; 31:1, 12) (like the seven days of creation) that conclude with the command to observe the Sabbath on the seventh day ${ }^{19}$. In both cases, in Genesis and in Exodus, the Sabbath is consecrated as the resting day, an expression of the eternal covenant between God and his people (Ex 31:16). It is interesting to remember the text of Revelation of Baruch (gr) 4:2-8 confirming this relationship between Gen 1-3 and Ex 24-31. Here we are told that God imagined the temple when he conceived paradise and that this plan was subsequently revealed to Abraham and then to Moses at Sinai. From here we understand the fullest meaning of the transformation of Moses at Sinai when he descended from it. As we know, once the Law is received, Moses comes down from the mountain with his radiant face as a result of the divine encounter

${ }^{18}$ MacDonald J. The Theology of the Samaritans. P. 400-401.

19 The future construction of the temple is presented, then, as the culmination of God's creative work and as a symbol of the creation of the cosmos. 
(Ex 34:29-35). This Adamic motive in Moses is explicitly exemplified in DtR 11.3:

Adam said to Moses: "I am bigger than you because I have been created in the image of God. How is this? It is said that 'God created man in his image"' (Gen 1:27). Moses replied: "I am far superior to you, because the honor given to you was taken away from you, as it is said: 'but man (Adam) does not reserve the honor' (Ps 99:13). But in my case, the radiant face that God gave me remains in me. How is that? Because it is said: 'His eye is not dark, nor is his natural strength dejected"' (Dt 34:7).

In general terms we can conclude saying that the heavenly realms became a place where remarkable characters as Moses are transfigured assuming divines' characteristics in an adamic way. The divinization of Moses is nothing but the recovery of the qualities that Adam shared with the divinity in the Garden of Eden. In fact, the adamic nature explains, in part, the ability of the human being to acquire the divine properties. As we have said Moses is not by far the only example. Enoch is another conspicuous case. Because the enoquic literature is so vast we will limit our next analysis to the Slavonic apocryphal of 2Enoch.

\section{The example of Enoch}

\subsection{Enoch ascends to a heavenly realm and he is transfigured}

The second example we will analyze about a heavenly journey is taken from the Slavic apocrypha of 2Enoch. The literature related to this son of Jared (Gen 5:18), who fathered Methuselah when he was 65 years old and lived up to

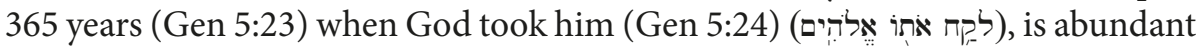
in the Judaism previous and post destruction of the second temple. Then, for instance, the 1Enoch consists of five works that were written in different historical periods ranging from approximately 230 or 190 B.C. (the astronomical book) until the middle of the first century (The book of parables). Not many years after the destruction of the temple the book we know as 2Enoch was composed and that has come to us in its translation to the paleo Slavic. Later, and this is a highly debated composition date, the 3Enoch or Sefer Hejalot was composed, which in general terms deals with the celestial journey of Rabbi Ishmael under the protection of the angel Metatron who in chapters 3-16 will reveal his true identity: Enoch, son of Jared.

In the 2Enoch, the heavenly journey and the revelations of the protagonist occupies much of the text. The story begins when two men of "huge stature"

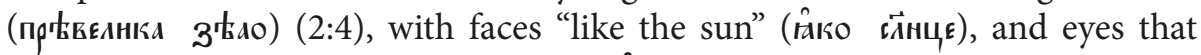
"looked like burning torches" (ск中цн Н̈зи) called him and warned that he would ascend to heaven (2:5). The cosmology presented by the apocryphal is quite elaborate. It consists of seven heavens through which Enoch is led by these heavenly beings who have placed him on his wings (на крнноо) (3:1). Thus, for example, in the first heaven they brought to Enoch's presence the lords and chiefs of the stellar orders, and "the two hundred angels that rule over the stars and 
the sidereal world flying with their wings around all the stars" were presented (3:4). Enoch could also see the deposits of snow, ice and clouds (3:5). Paradise, meanwhile, is in the third heaven and it is described in the next way:

A place of incomprehensible goodness, where I could see (Enoch speaks) all kinds of trees in full bloom, whose fruits were in season and smelled pleasantly. I also saw foods of all kinds that had been brought there and gave off a very soft aroma when boiling. And in the center was the tree of life (погрь дрєво жндньно), precisely in the same place where the Lord usually rests when he goes up to paradise [reference to the throne divine] (5:2-3).

An interesting aspect of paradise lies in its location, between corruption (та中нї) and incorruption (нєтл'ннї) (5:4), in other words, between the "divine" and the "human".

Referring to the myth of the Book of the Watchers ${ }^{20}$, Enoch finds in the fifth heaven an "innumerable number of warriors called grigori (грнгорє)" (2Enосh $7: 2$ ), these are those who apostatized from the Lord along with his leader Satanael staining the earth with his misdeeds, mixing with the daughters of men and begetting the great giants (7:8). Enoch, in the high priestly manner, pray for

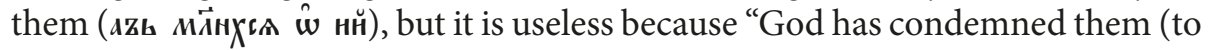
be) under the earth until the end of it and the heaven forever" (7:11). In the sixth heaven, Enoch saw "seven formations of angels, (all) very bright and glorious (прыскытан $\hat{\mathbf{H}}$ слақны) in extremes: his face was brighter than the rays of the sun in all its vigor and could not appreciate differences (between them), neither in its face, nor in its external figure, nor in the attire of its dress" (8:1). The Lord, meanwhile, enjoyed (pâyжтгs) from his pedestal (8:7). In the seventh heaven everything is even more splendid. In the distance, sitting on his high throne, was

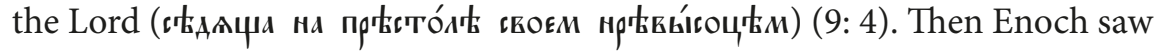

Like the heavenly armies, after entering, they were placed in ten tiers according to their category and worshiped the Lord, then retiring to their happy and joyful posi-

${ }^{20} \mathrm{M}$. Segal reminds us that The book of the watchers has as its main function to clearly differentiate the celestial spheres from the human ones so that the limits are not transgressed, which finally happens as is typical in apocalyptic literature. The basic text of the story is in Gen 6:1-4 that 1Enoch interprets, through two traditions, as a human rebellion against God led by vigilant angels. The first tradition has as leader the angel Semyasa who with his followers descends from the heavens to have sex with women and father children who were the giants (1Enoch 6:17:6). The second tradition has as its protagonist the angel Azazel who with his descendants descended to earth to teach men an important amount of forbidden knowledge such as making swords, knives, shields, how to beautify, make and undo spells etc. (1Enoch 8:1-4). Therefore, these sons of God (ינֶר מיהלקָָה) of Gen 6:2 are rebel angels led by Semyasa, according to one tradition, and of Azazel, according to the other, that, reading the work as a unit, not they only joined with women, but also transmitted forbidden knowledge. The transgression between the celestial and terrestrial limits was clearly crossed. The disobedience of these angels really bothered God, who not only limited the presence of his spirit ("life") in man, but declared an unappealable sentence against the watcher angels (1Enoch 13:2b). For more details: Segal M. The Book of Jubilees, Rewritten Bible, Redaction, Ideology and Theology. Leiden: Brill, 2007. P. 104. 


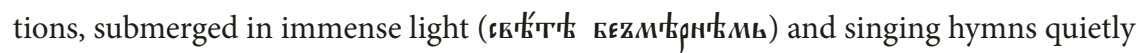
and softly (9:4).

One motive that is repeated before the divine theophany and consequent Adamic transformation of the visionary is the fear they feel before the "power" and "glory" of God. It is as if the "lightness" of the human being became aware of his "nothingness" before the divine "power». This motif is already present in 1Enoch when, for example, in front of the Great Majesty sitting on a high throne from which rivers of scorching fire emanate, the protagonist falls face to the earth trembling (1Enoch 14:22). And it is that "the aspect of the face of the Glorious and Excels cannot be seen by any carnal man" (1Enoch 14: 21). In the 2Enoch the fear of theophany is repeated more frequently $(9: 2,3,6,7,8$, 10). So when, in front of the face of the Lord, the two angels who had accompanied Enoch on his heavenly journey leave him the patriarch falls on his face (падо на ли́цн гвов) and exclaims:

Oh my! What just happened to me? Then the Lord sent one of his glorious archangels, Gabriel, who told me [to Enoch]: "Have courage (Арьzaн), Enoch, and do not fear (нє вон́сє); get up, come with me to remain before the face of the Lord forever (гтаи́н

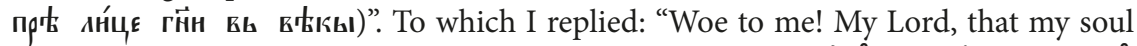

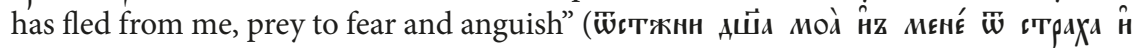
ТрєпєТА (9:6-8).

Of course, the reason for human fear before the absolute of God is already found in the account of Moses in Sinai. Indeed, when Moses brought the people closer to Mount Sinai during the dawn of the third day, "there was thunder and lightning, with a thick cloud over the mountain, and a very loud trumpet blast. Everyone in the camp trembled" (Ex 19:16). The fear was not only justified from the presence of God, but also by the divine warning against the priests and the people in the sense that if anyone tried to cross the boundaries to

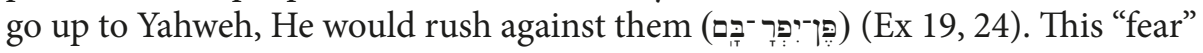
of God, which is nothing more than the recognition of human "nothingness" in relation to the divine "absolute", will be a very present motive in the heavenly journeys of apocalyptic literature ${ }^{21}$. It is important to reflect that this "fear" is

${ }^{21}$ In the case of Isaiah's vision he exclaims before Yahweh: "And I said: 'Woe to me! For I am lost! (כי־נְרנטיתית). For I am a man of unclean lips, and I live among a people of unclean lips, and my eyes have seen the King, the Lord Almighty"' (Isa 6:5). This case is interesting because the meanטמד ing of the niphal implied "being destroyed", while related to this one we find the verb which in niphal means "to be silenced". This means that on the one hand Isaiah can be destroyed before the vision of God, or lose the ability to speak because the vision is verbally inexpressible. Another example of the fear of the visionary is found in the $A p A b$ when the angel Yaoel who leads Abraham to the throne of God tells him: "Stay close to me and do not fear (не бойся), because He whom you cannot see is coming now towards us with a great voice of holiness, the Saint who loves you $\langle\ldots\rangle$. Do not let your spirit be weakened (Пусть не слабеет дух твой) by the chorus of shouting voices, because I am by your side to strengthen you" ( $A p A b 16)$. Recall also that in the Slavic apocryphal Jacob's ladder when the protagonist hears the voice of God coming from above, "an astonishment and a tremor" (трєпєть н оүжась) seized he (EscJac B 2.1). Let us also mention 
the sensitive expression of divorce between man and God when the former is expelled from the Garden of Eden. In other words, just as the fear of God is present in the experience of Moses and Enoch, so is it in a paradigmatic way in the experience of Adam after disobedience before being expelled from the Garden of Eden. And, as we already know, the fear of God is not the only characteristic that Moses and Enoch share with Adam. The divine qualities of the first man when he lived in the Garden of Eden will be the same as those that Enoch will acquire according to the Slavic apocrypha.

\subsection{The adamic character of the Moses's transfiguration}

This last idea in relation to the fear of God is important. Let us remember that the fear of the first couple was manifested for the first time after disobeying the divine commandment, seeing themselves naked and being in the presence of God. And, when Adam and Eve, aware of their precariousness after their disobedience, heard the footsteps of Yahweh walking through the Garden, they hid because they were afraid (וירו) of their nakedness (Gen 3:8-10). The same idea, although more developed, is found in the Greek version of LifAd. In this apocryphal text, God enters the Garden sitting on a throne carried by the

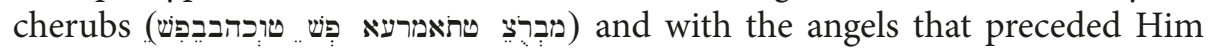
singing hymns of praise (22:3). Then God asks for Adam, who, when presented before divinity, recognizes that he has hidden because he was afraid of his na-

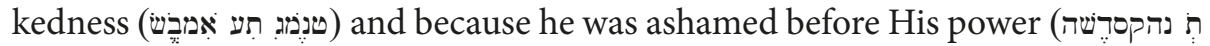
(23:2). The Slavic version is even more expressive about it by putting the following words in the mouth of the first man: "Lord, I heard your voice and I felt terribly scared because I was naked". In a similar way, in the 2Enoch when Enoch is in the seven heaven and contemplates the presence of God with all his celestial servants is terrified and falls on his face and exclaimed: "Woe to me! What has happened to me?" (2Enoch 8:6). In another version (J) of this apocryphal the words of Enoch are more impressive: "Woe to me, my Lord! My soul has departed from me from fear and horror. And call (to me) the two men who brought me to this place, because I have put my confidence in them, and with them I will go before the face of the Lord" (2Enoch 8:8).

the Apocalypse of Zephaniah where the protagonist fell on his face and began to plead before the almighty Lord when all his sins are curled up (ApSof 7:8). Finally, let us mention that in the Jesus'

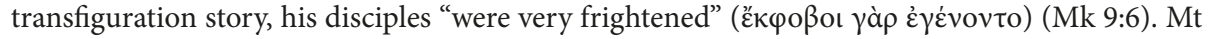
is more specific than $\mathrm{Mk}$ in this aspect of the theophany in describing that the disciples "fell face

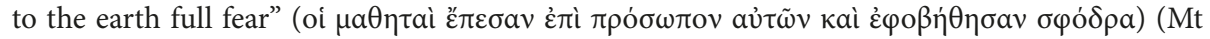
17:6). It is in this context of theophany that we hear the voice of God exclaiming: "This is my

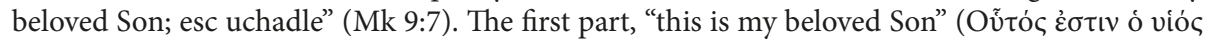

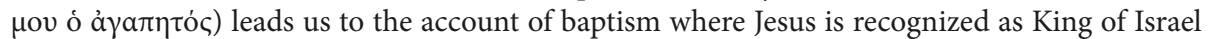
in reference to the Enthronement Ps 2: 7. The second part, "listen to him" identifies the figure of Jesus with the prophet as Moses promised in Deut 18:15 and with the angel of the Lord of Ex 23: $20-22$. 
This analogy between the fear of the visionary, in this case Enoch, with the fear of the first couple once they find themselves naked before the "power" and "glory" of God implies recognizing the nothingness of human "life". This contrast between the human condition and God's glory is most evident when we consider the divine characteristics that are expressed in the theophany of 2Enoch. As we have already seen, in this book the Lord appears sitting on his high throne (2Enoch 9:2), but even more impressive, Enoch contemplates him "face to face"

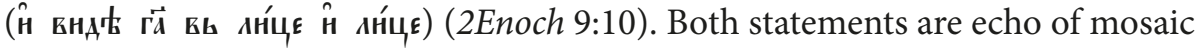
traditions. Indeed, according to the Exagogue, Moses contemplates God on high, sitting on a throne so high that he touched the clouds of heaven, while others

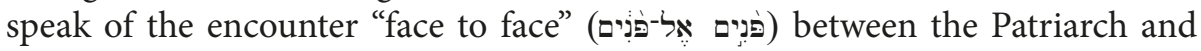
divinity (Ex 33:11). Now, when Moses asks God to show him his "glory" (די כב (Ex 33: 18), He replies that His goodness will pass before him and that he

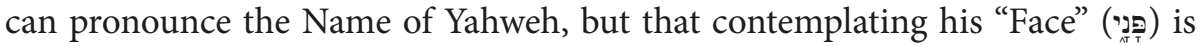

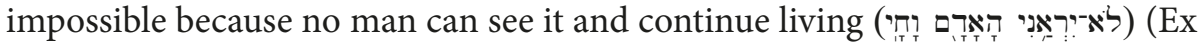
33: 20). This restriction is absent in the tradition of 2Enoch. Enoch is not only placed "face to face" with God, but he is able to describe what he sees and feels:

Who am I to describe the unstoppable essence of the Lord, his admirable and ineffable face (лнце єго прЊди́кно $\hat{\mathbf{H}}$ нєнєновЊднмов), the well-instructed choir with many voices, the immense throne not handmade, the choirs that are around it and the armies of the cherubs and the seraphim with their incessant chants? And who will finally be able to outline the image of her unchanging and unspeakable beauty

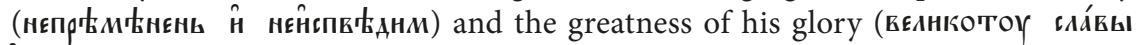
Eго)? (2 Enoch 9:11-14).

The description of the divine face, however, is made even more explicit in chapter 13 where the protagonist tells his children about his encounter with God.

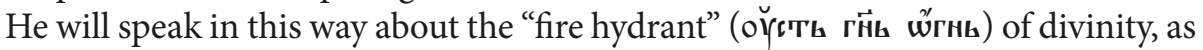
if it were "a burning furnace" (пє́щь шгньна) (13:3). The face of the Lord would be like a "hot iron (жєA'tzo $\mathbb{w}$ w̆ wrнt) which, when removed from the fire, emits sparkles and burns" (13:5). The eyes of the Lord, on the other hand, are "like a beam of sun rays ( 18 Y E с $\mathbf{1}$ iा the Lord covers the whole sky, and that is that the volume of divinity is immeasurable and incomparable. It knows no limitation (13:7-8). Finally, his voice is like "great thunder (гром $\mathbf{E} \boldsymbol{\varepsilon} \mathbf{A} \mathbf{H})$, amid the incessant confusion of the clouds" (13: 9).

In the manner of Moses and Adam, the face of Enoch himself will also be transfigured reflecting the divine glory. We know that according to the Latin version of the LifAd the face of the first man was created in the likeness of God. Other sources are consistent in pointing to the brightness that Adam reflected in the Garden of Eden (Gen 12:6; b.Hag 12 $2^{\text {th }}$ ). This explains that Moses descending from Sinai, and every time he spoke with God, he radiated the divine radiance so that he would wear a veil every time he spoke with the people (Ex 34:29-35). Moses was in the manner of a second Adam before God. And the same can be said of Enoch. Indeed, and according to Enoch himself, the Lord called one of his principal angels who 
He cooled my face, for I could not bear the fear that the Lord infused me, in the same way that it is not possible to withstand the fire of an oven, nor the heat of the sun, nor the frost of the weather. And the Lord said to me: "Enoch, no man can look you in the

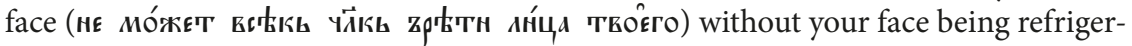
ated here" (2Enoch 12:3-4).

Now, the inability of people to look him in the face is not the only expression of the glorious or adamic condition adopted by Enoch after his encounter with God. Indeed, from the biblical account we are told about the Adamic character of

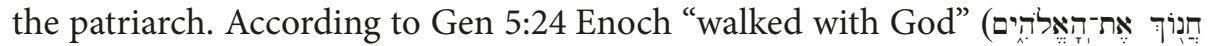

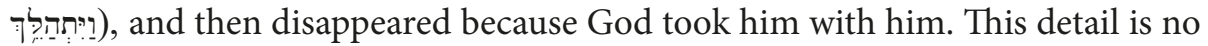
less important because we know that after Adam's expulsion from the Garden, God had not walked with any man.

The Slavonic apocrypha of 2Enoch, then, gathers this Adamic quality of the patriarch to explain in a special way his transformation in the heavens. Indeed, when the patriarch stands before the throne of God, the archangel Michael stripped him of his earthly garments (сь zємнн рні́z)), anointed him with a good oil that looked more resplendent than of a great luminaire; and he dressed him in his glory (the divine) (вь рнды сла́вы мов̆ж) (2Enoch 9:20-21). To this point came the angelic transformation of Enoch, who proved that he was "like one of

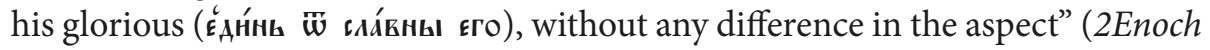
9:23). It is important to remember that in the same apocryphal, when talking about Adam, it is said that God had established him on earth as a "second angel"

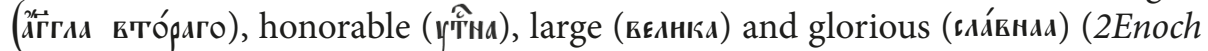
13:60). Enoch's metamorphosis is explained, therefore, through the recovered Adamic condition. At the same time, it is this adamic nature of Enoch (as in every human being) which able him to go through a process of divinization. In addition, Enoch knows, among many other things, everything he has recorded in the books: the heavens with their confines (2Enoch 13:12); the number and names of all the angels (2Enoch 13:13); all the seeds produced by the soil and all kinds of vegetables (2Enoch 13:17). This quality reminds us of Adam in Gen 2:19-20 who also had a finished knowledge of creation to the point of naming

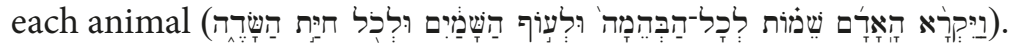

Finally, let us mention that when Enoch's son, Methuselah, "called his brothers Regim, Riman, Uchan, Chermion and Gaidad, as well as all the elders, citing them before the face of their father Enoch, they fell down before him" (2Enoch 14:6). This situation is very interesting because it seems to reverse what the LifAd had already told us about when the angels refused to adore Adam, the "image" of God. Indeed, as we know, when Adam was created, Michael, following God's orders, gathered all the angels and said: "Come, prostrate before God whom I have created" (Armenian version 14:1). Satan refused to do so to consider it a humiliation. After all he had been created before the first man which means that he was more important. From this point of view, Enoch, as a glorious second Adam, is revered by his own. Enoch reverses the faulty history of the first angels. 


\section{Conclusions}

The two examples discussed in this paper, among many others, are particularly important for several reasons. According to different canonical and apocryphal texts, certain heroes of the Old Testament can access to the heights, either ascending under the guidance of a celestial being, or, through revelations that occur on earth. As a product of these visions, these heroes are transfigured in the presence of God. The important thing is to notice that many of God's own qualities will be acquired by these characters: "luminosity", "immortality", "power", "royalty", the "throne", etc. It is as if these divine qualities did not essentially define God, but that He could dispose of them at will. The essence of God is beyond the properties which defines Himself. On the other hand, although these divine properties are unmerited gifts from God to the visionaries, there is something which enables the person to assume "luminosity", "immortality", "power", and "royalty", among others. The Adamic quality of the human being is what explains why he can assume such divine characteristics. After all, already in the Garden of Eden the human being reflected the "glory" and "power" of God.

\section{References}

Anderson G. A., Stone M.E. (eds). (1999) A Synopsis of the Books of Adam and Eve. Atlanta, SBL Publ.

Díez Macho A. (ed.). (1983) Apócrifos del Antiguo Testamento, vol. II, Madrid, Cristiandad Publ. Fletcher-Louis C. (2002) All the Glory of Adam. Liturgical Anthropology in the Dead Sea Scrolls. Leiden, Brill Publ.

Gieschen C. A. (1988) Angelomorphic Christology: Antecedents and Early Evidence. Leiden, Brill Publ.

Halladay C. (1989) Fragments from Hellenistic Jewish Authors, vol. II. Atlanta, Scholar Press.

Hurst L. D., Wright N. T. (eds). (1987) The Glory of Christ in the New Testament. Oxford, Oxford University Press.

Josefo F. (2013) Antigüedades de los judíos (Ant.). Barcelona, Cloe Publ.

MacDonald J. (1964) The Theology of the Samaritans. London, SCM Press.

Marcus R. (1963) Philo, Questions and Answers on Exodus. Cambridge, Harvard University Press.

Marcus R. (trad.). (1963) Philo, Questions and Answers on Exodus. Cambridge, Harvard University Press.

Orlov A. (2019) The Glory of the Invisible God, Two Powers in Heaven Traditions and Early Christology. London, T\&T Clark Publ.

Segal M. (2007) The Book of Jubilees, Rewritten Bible, Redaction, Ideology and Theology. Leiden, Brill Publ.

Triviño J.M. (trad.). (1976) Obras Completas de Filón de Alejandría, vol. IV-V. Buenos Aires, Acervo Cultural Publ.

Received: June 06, 2020

Accepted: July 21, 2020

Author's information:

Tomas Garcia-Huidobro — Priest, Doctor of Biblical Theology; tomachosj@gmail.com 


\section{T. Гарсиа-Уидобро}

Папская коллегия Руссикум в Риме,

Италия, 00185, Рим, Виа Карло Каттанео, 2А

Для цитирования: Garcia-Huidobro T. Transfiguration of Moses and Enoch on Heaven and the Adamic condition // Вопросы теологии. 2020. Т.2, № 3. С. 390-408.

http://doi.org/10.21638/spbu28.2020.301

В иудаизме Второго храма, особенно в апокалиптической литературе, встреча между Богом и верующими приобретает выраженный визионерский акцент. Независимо от того, открываются ли небесные реалии на земле или визионер возносится на небеса, суть заключается в манифестации важных откровений. Соответствующие персонажи Ветхого Завета, такие как Енох или Моисей, согласно апокрифическим, самаритянским или раввинистическим текстам, возносились к месту присутствия Бога (выглядело ли оно как тронный зал или как облако), где, помимо обретения важного сотериологического и космологического знания, испытывали преображение. Преображение этих персонажей весьма показательно: они принимают ангельские, царские, священнические признаки. Божественное сияние, блистающие лица, великолепные одеяния - вот лишь некоторые примеры приобретенных божественных свойств. В статье рассматриваются эти элементы и подчеркивается, что такие божественные качества описывались в литературе I в. до н.э. - I в. н. э., посвященной Адаму до его изгнания из Эдема. Близость между первым человеком и Богом в Эдемском саду выражалась в ряде божественных свойств, присущих Адаму, - тех же самых, которые позднее воспримут среди прочих Енох или Моисей на небесах. Таким образом, преображение Еноха или Моисея есть не что иное, как проявление богатой иудейской антропологии адамического характера.

Ключевые слова: Адам, Моисей, Енох, преображение, небеса.

Статья поступила в редакцию 6 июня 2020 г. Статья рекомендована к печати 21 июля 2020 г.

Информация об авторе:

Гарсиа-Уидобро Томас - священник, д-р библейского богословия; tomachosj@gmail.com 